\title{
PAN-IDEOLOGIES IN THE OTTOMAN EMPIRE AGAINST THE WEST: FROM PAN-OTTOMANISM TO PAN-TURKISM
}

\author{
YELDA DEMİRA Ğ
}

\begin{abstract}
After the Karlowitz Treaty of 1699, the Ottoman Empire began to lose constantly in every field, when compared to European gains in economy, territory, industry and social changes. The ideas of the Enlightenment such as positivism and nationalism also undermined the foundations of the Ottoman social system (millet) that gave a common sense of identity to all the communities of the Empire. Beginning from that time, the Ottoman bureaucracy began to search for the meaning of being European. The most important question was what should be done in order to save the Empire. The first solution found for the problem was the reorganization of the Ottoman Army which was superior in comparison to its European counterparts. As it became obvious that this attempt was not enough, using Western values against the West by arrangements on education and diplomacy, and when these failed too, it was attempted to change the legal sphere by introducing Western secular values to coexist with Ottoman sharia system. These attempts made to prevent stagnation and decline from the $17^{\text {th }}$ century onwards, did not prevent the decline of the Empire. In the $19^{\text {th }}$ century, it is seen that some currents of thought emerge among the Ottoman intellectuals. The common point of all these currents was to save the "sick man of Europe" as uttered by the Russian Tsar, but the proposal differed. This study will discuss Pan-Ottomanism, which started in the mid- $19^{\text {th }}$ century as an ideology of unity, but developed to be a nationalist ideology in the early $20^{\text {th }}$ century against the independence demands of the Ottoman non-Muslim as well as Muslim communities. The study will also discuss the influence of Ottoman pan-ideologies in the establishment of modern Turkey.
\end{abstract}

\section{KEYWORDS}

Ottoman Empire, Pan-Ottomanism, Pan-Turkism, Pan-Islamism, Occidentalism. 
Although the Ottoman lands reached the Danube and near Vienna from the Balkans and even as the lands of the Ottoman Empire contained one third of Europe, it was not accepted as a European power, because of the religious affiliation which differed it from the others in Europe. ${ }^{1}$ In fact, the Ottomans had no wish towards being recognized as such for they considered the Empire as superior to the other states of the continent. To be considered as equal and to establish diplomatic relations on equal basis with the West was undesirable for the Ottomans. In this context, foreign ambassadors were accepted to Istanbul, but no ambassador was sent abroad on a permanent basis, since it is not accepted by the Ottoman sultans that they were equal to their European counterparts in the agreements they concluded. The letter sent by Süleyman the Magnificent to his ally French King, François I is a good example of this. ${ }^{2}$ Also, for a long time European rulers were treated only as equivalent to the Ottoman Grand Vizier. Not until the peace treaty of Zsitva-Torok in 1606 was the ruler of Austria recognized by the Porte as having the status of emperor (Nemçe Châsârl). ${ }^{3}$ All agreements were unilateral documents. This treaty dated 1606 was the first sign of the relationship emerging between the Ottoman Empire and the Europeans which would be wholly shaped with the 1699 Karlowitz Treaty.

Until the Karlowitz Treaty which constitutes a turning point for the Empire, the Ottoman relations with the Western states were handled in such a manner. In 1699, a mutual agreement, instead of the

${ }^{1}$ For further information see; J.C. Hurewitz, "Ottoman Diplomacy and the European State System”, Middle East Journal, Vol.15, 1961, pp. 145; T. Naff and R.Owen, "The Ottoman Empire and European State System", in H.Bull and A. Watson, The Expansion of International Security, (Oxford, 1992), pp. 143-164.

${ }^{2}$ Suleyman the Magnificent's letter to the French King begins as "I who am the sultan of sultans, the sovereign of sovereigns, the distributors of crown to the monarch of the surface of the globe, the shadow of God on earth,..........; You who are Francis, king of the land of France....". Roderic Davison, Turkey, (New Jersey: Prentice Hall, 1968), p. 47.

${ }^{3}$ Bülent Arı, "Early Ottoman Diplomacy: Ad Hoc Period", in Nuri Yurdusev (Ed.), Ottoman Diplomacy: Conventional or Unconventional, (Basingstoke, Palgrave, 2004),p. 42. 
"single-sided pledge given to God", ${ }^{4}$ by the Ottomans, was singed for the first time. With this treaty, for the first time in its history, the Ottomans accepted to be on equal status with other states. ${ }^{5}$ The reasons that actually drove the Ottomans to act this way were the facts that it has been a century since the time of Suleyman the Magnificent, that the Ottomans had no more their old strength, and that they realised their role in Europe at that time was defense. 1699 is the year that the decline of the Empire began and that the Ottomans understood their current political, military, and economic positions were not as good as those of Europe, and began to attempt at solving these problems.

Beginning with that time, the Ottoman bureaucracy began to search for the meaning of being European in political and social terms. The most important question was what should be done in order to save the Empire. It was thought that the decline might be stopped by adopting the military techniques of the West which managed to beat the Ottoman army which was thought once unbeatable. The ambassadors sent to the West at the end of the $18^{\text {th }}$ century focused mainly on this issue. For instance, Ahmet Resmi Efendi who was sent to Prussia in 1763 mentioned with commendation the discipline of the Prussian Army in his Sefaretname (Consulate reports). ${ }^{6}$ As Lewis states that the Ottomans have not adopted the new military technologies was not because they were unaware of the developments, but because of the troubles that the Ottoman economy faced $^{7}$ as they had previously adopted such technologies. As the value of the Ottoman currency devalued while the prices of the raw material imported from Europe rose, some modern developments in the military industry could not be traced, and that served to the decline of the Ottoman army against the West. ${ }^{8}$ In the meantime, another point

${ }^{4}$ Halil İnalcık, "III. Selim'den Önce Osmanlılarda Diplomasi”, Çağdaş Türk Diplomasisi: 200 Ylllk Süreç Sempozyumu, (Ankara: TTK Yayınları, 15-17 Ekim 1997), p. 43.

${ }^{5}$ Ahmet Reşit, Hukuk-ı Umumiyye-i Düvel, (İstanbul, 1932), p. 87.

${ }^{6}$ Ahmet Resmi, Sefaretname, (İstanbul, 1303), p. 33.

${ }^{7}$ Bernard Lewis, The Emergence of Modern Turkey, (New York: Oxford University Press:2002), p. 42.

${ }^{8}$ Niyazi Berkes, Türkiye'de Çağdaşlaşma, (İstanbul: Yapı Kredi Yayınları:, 2002), p. 76. 
the Ottomans missed were the developments that were at the foundation of the technical developments in the West. The scientific developments had begun in Europe at the $14^{\text {th }}$ and $15^{\text {th }}$ centuries including the Renaissance, and from the $17^{\text {th }}$ century these theoretical developments were applied to technology. ${ }^{9}$ During the reigns of Selim III and Mahmut II, it was understood that the Western supremacy was not limited to the technical field and the reforms were widened to include diplomacy and education. ${ }^{10}$ As it was understood that these were not enough by themselves, then, the judicial system was revised. However, these efforts neither prevented the decline of the Empire nor provided a sound base for identity in its communities. Instead, the reforms destroyed the traditional order, but never replaced them with a new and workable one. Under these circumstances, the $19^{\text {th }}$ century witnessed many debates among the Ottoman intelligentsia for the political orientation of the Empire. ${ }^{11}$ This paper will focus on these debates namely; Pan-Ottomanism, PanIslamism, Pan-Turkism and Westernism. The main aim of these ideologies was common; to save the Empire from collapse, however there was no strict distinction between them. The paper will also try to analyze the impact of these ideologies on modern Turkey in the conclusion.

\footnotetext{
${ }^{9}$ Ekmeleddin İhsanoğlu, "Some remarks on Ottoman Science and its Relation with European Science and Technology up to the End of the Eighteenth Century", Journal of the Japan-Netherlands Institute. "Proceedings of the International Congress on the Transfer of Science and Technology Between Europe and Asia Since Vasco de Gama", (1:5-7 June 1991, Amsterdam), 3, (1991), 45:73.

${ }^{10}$ During the reign of Selim III, permanent embassies were established at major European capitals. Again in this period, new schools such as the Engineering School (Mühendishane) where foreign teachers lectured. Under the reign of Mahmut II. Naval Medical School, and the Maritime School were established and teaching of French in addition to Turkish was decided. For further information on further reforms in the Selim III period, see Enver Ziya Karal, Selim III'ün hatt-l hümayunları, (Ankara: TTK Basımevi, 1999); Enver Ziya Karal, Osmanlı Tarihi, (Ankara:TTK Basımevi, 1988), pp. 13-73.

${ }^{11}$ Şaban Çalış, "The Origins of Modern Turkish Foreign Policy: Ottoman Psychological Background", Foreign Policy, Vol. XXVII, No.3-4, 2001, p. 59.
} 
Until the end of the $19^{\text {th }}$ century, Ottomans had no "ethnic policy" nor did they value the idea of being Turks till that time. Although it was based on a theocratic structure from the beginning, the Ottoman State has given its minorities the chance to preserve their ethnic and religious identities in peace ${ }^{12}$ within the Ottoman "millet system". ${ }^{13}$ Although the primary reason for the Ottomans to adopt such a system was Islamic law, the changes in economic and administrative conditions were of great importance too. The change in the trade routes after the European discoveries of the $15^{\text {th }}$ century affected the economic life of the Near East negatively and the Ottomans had to adopt new precautions to revive the trade activities in the region. Especially during the reign of Mehmet II, the Venetians and Genoese practicing trade had been given extensive rights and the non-Muslims who accepted the Ottoman rule were given the rights of free belief. Again in this period, the Greek Orthodox Patriarchy was revived and further religious and legal rights were awarded to the Patriarchy than it was given in the Byzantine period. In the same way, the Jews were given the right to keep their own synagogues, and the Armenians were appointed a patriarch and hence the balance between the different communities was kept. ${ }^{14}$ Each faith was set free to establish an order according to its own beliefs. In fact, the strengthening of the religious and then their ethnic identities which turned into their modern political identities for the minorities living in the Empire were experienced under the millet system which stayed in practice for 400 years. ${ }^{15}$ This benign rule of the Ottomans which helped minorities preserve their identities was a helping factor in the fact that the nationalist movements managed to find niches in the

${ }^{12}$ Stanford Shaw, says on the subject that the Ottomans neither attempted at enslaving the Judeo-Christian populations of the lands they conquered and nor did they force conversion on them. The problems created by the Ottoman minorities are the consequences of the tolerant administration the Ottomans gave them for the previous five hundred years. S. Shaw, History of the Ottoman Empire and Modern Turkey, (Cambridge: 1977).

${ }^{13}$ The millet system in the Ottoman Empire signifies religious community. For further information about Ottoman "millet system" see; B. Eryılmaz, Osmanlı Devletinde Millet Sistemi, (İstanbul, 1992).

${ }^{14}$ İlber Ortaylı, "Osmanlı İmparatorluğu'nda Millet”, Tanzimattan Cumhuriyete Ansiklopedisi, Vol. IV, (İstanbul:1985), p. 998.

${ }^{15}$ Kemal H. Karpat, Balkanlar'da Osmanlı Mirası ve Ulusçuluk, Çev. Recep Boztemur, (Ankara: İmge Yayınları, 2004), pp. 14. 
Empire in the wake of the ideas of "everyone was created equal" in America and "human and citizen rights" in France during the late $18^{\text {th }}$ century. The zımmis (non-Muslim subjects) who benefited from their links with the West as well as their immunity from military service confronted the Empire with secessionist demands. ${ }^{16}$ The European powers that were not late to make use of these demands of the nonMuslims adopted the policy of the protection of the minorities, and began to make pressure on the Empire for reforms to benefit the zımmis. As a result of the emergence of nationalist ideas among the Ottoman communities and the support given to them by the Great Powers in the early $19^{\text {th }}$ century the Ottoman Empire had to accept the independence of Greece, the autonomy of the Walachia and Bogdan, and Serbia. In this century, reform movements halted the disturbances in the Empire on the one hand and avoided the interventions of the Great Powers on the other. The statesmen of the Tanzimat era aimed at both achieving Westernization and uniting those living within the Empire around the spirit of Ottomanism and keep the state intact. The birth of the thoughts on the creation of an Ottoman identity and then an Ottoman nationality among all ethnic groups within the Ottoman Empire as to have the Ottoman communities to act in accordance with the benefits of the Empire are also marked in this era.

\footnotetext{
${ }^{16} \mathrm{Had}$ the Ottoman State made pressure on the minorities and attempted at converting them as some prejudiced researchers argue, such a problem might not be encountered in the 19th century. Although there were some restrictions imposed on the non-Muslims, these worked to their advantage and not to their disadvantage. For further information on the situation of the non-muslims living in the Ottoman Empire, see Yelda Demirağ, "Osmanlı İmparatorluğu'nda Yaşayan Azınlıkların Sosyal ve Ekonomik Durumları", OTAM , No. 13, offprint, (Ankara. AÜ Basımevi, 2003), p.1533; Bernard Lewis and Benjamin Lewis Braude, (eds.) Christians and Jews in the Ottoman Empire, (New York: 1982); Yavuz Ercan, “Türkiye'de XV. Ve XVI. Yüzyıllarda Gayrimüslimlerin Hukuki, İçtimai ve İktisadi Durumu", Belleten Dergisi, cilt: XLVII, 1983, p.1143; Charles Issawi, "The Transformation of the Economic Position of the Millets in the 19th Century", in Bernard Lewis and Benjamin Braude (eds.), Christians and Jews in the Ottoman Empire, p. 261.
} 


\section{Pan-Ottomanism}

The ideas of nationalism that the French Revolution has spread have shown their effects on the Ottoman society as well and caused the 1821 Greek Rebellion. The Ottoman elite began to seek a new identity to counter the nationalist feelings awakening in the Ottoman society which was previously organized under the "millet" system and believed they could only be successful against the nationalist current by a version of nationalism which would give everyone an overall identity. In other words, they tried to create an identity of Ottomanism which would shove the national identities emerging in the minorities of the Empire. Pan-Ottomanism is a current of thought which aims at creating, over all the nationalities of the Ottoman Empire, a we-feeling of being Ottoman and an "Ottoman nation" in parallel with this feeling. The main idea was the principle of ittihad-l anasir (the unity of components) taking each millet as an equal part of a greater Ottoman nation. It was based on two main assumptions: First; the non-Muslim subjects of the Empire could no longer be gathered under the umbrella of the ancient regime allowing a dominant position to Muslims. Second; introducing more Islamic or nationalist policies was a more divisive approach, which would lead to further secessionist demands. ${ }^{17}$ In fact, the idea of creating an Ottoman nation marks back to the words of Mahmut II who stated "I identify my Muslim subjects in the mosque, Christian subjects in the church, and my Jewish subjects at the synagogue. There is no difference between them. For all my justice is equal and all of them are my true children". 18 The 1839 Gülhane Hattı Hümayunu accepted his arguments by defending the equality of all Ottoman subjects

${ }^{17}$ Çalış, "The origins ...", p. 53-75; also see, E. Mortimer, Faith and Power: The Politics of Islam, (London:1982), pp. 126.

${ }^{18}$ For the reforms of Mahmud II period see; Uriel Heyd, "The Ottoman Ulema and Westernization in the Time of Selim III and Mahmud II", Scripta Hierosolymitana, Vol.IX, Studies in Islamic History and Civilization, (Jerusalem: 1961), p. 63-96; Avigdor Levy, "The Ottoman Ulema and the Military Reforms of Sultan Mahmud II", Asian and African Studies, Vol. 7, 1971, p. 13-40. 
before the law regardless of their religious beliefs. ${ }^{19}$ However, the Tanzimat reforms failed to prevent the rise of secessionist ideas among the non-Muslim subjects within the Empire and besides it has attracted reactions from the Muslims for being equal to nonMuslims. ${ }^{20}$ Another opposition group against the Tanzimat reforms was within the reformers themselves. This group named as the "Young Ottomans" claimed that the 1839 (Gülhane Hatt-l) and 1856 (Islahat) decrees were documents invigorating imperialism and that Ali and Fuat Pashas were the men of the West due to their economic policies. According to the Young Ottomans, the Tanzimat could not go beyond being a cultural imitation, and has shaken the Muslim community fundamentally. According to such representatives of the group as Sinasi and Namı Kemal, the solution laid in the establishment of a representative, constitutional, and parliamentary administration and hence in the creation of a full loyalty in all subjects of the empire, Muslim or non-Muslim. ${ }^{21}$ Namık Kemal wanted the continuation of the mixture that made up the Ottoman Empire and defended the idea of Ottomanism as it was not possible to grant a nation state for each ethnic group; all should be loyal and connected to the Ottoman Empire.22 In that sense, the Young Ottomans who criticized the statesmen of Tanzimat for imitating the West were also taking the West as their example. They hoped that if the Empire was furnished with more liberal institutions and if there was equality of citizenship before the laws for all the subjects, then it would be possible to save the country from collapse quickly and preserve its unity and integrity in the long run. ${ }^{23}$ Although the Young Ottomans differed from Ali and Fuad Pasha on many issues, there

${ }^{19}$ Karal, Osmanlı Tarihi, Vol. V, p. 171.

${ }^{20}$ For reactions against the Tanzimat movement, see Engelhardt, La Turquie et le Tanzimat ou Histoire des Reformes dans L'Empire Ottoman, (Paris:1882), Cevdet Paşa, Tezakir, Yayınlayan: Cavid Baysun, (Ankara: TTK Basimevi, 1991); Roderic Davison, Reform in the Ottoman Empire1956-1976, (Princeton: 1963); Halil İnalc1k, "Tanzimatın Uygulanması ve Sosyal Tepkileri”, Belleten Dergisi, 1983, C.20, p. 43.

${ }^{21}$ Erik Jan Zürcher, Modernleşen Türkiye'nin Tarihi, (Trans.by Yasemin Soner Gönen), (İstanbul: İletişim Yayınları, 2000).

${ }^{22}$ Şerif Mardin, The Genesis of Young Ottoman Thought: A Study in the Modernization of Turkish Political Ideas, (Princeton: Princeton University Press), 1962.

23"The Origins ...," s. 
were two common points between them: the attempts to save the Empire and to create a concept of Ottomanism to make nationalism fade into the background. ${ }^{24}$ As stated above, when one analyzes constitutionalism defended by the Young Ottomans, it is clearly seen that it aims at limiting the sultan's capabilities but another issue is to prevent any further dismemberment within the empire by establishing a system in which all are equal under a parliamentarian system. Despite all these attempts, it will be understood in a while that the idea of Ottomanism was not accepted among the minorities of the Empire, because nationalism is grounded, and beside the Muslims saw the idea of the equality of all citizens as an unacceptable phenomenon. With the loss of some lands of the Empire in the Balkans after the Ottoman-Russian War in 1877-78, the Arab and Muslim elements were now becoming more important in the Empire in comparison with the past. It is from that time onwards that the idea of replacing Ottomanism with Muslimness began to gather strength.

\section{Pan-Islamism}

During the reign of Abdülhamit II, the ideology of Muslim unity, Pan-Islamism, grew in importance. In fact, Islamism and the idea of being against the West were discussed before Abdülhamit II came into power, what he did was to adopt it as an official ideology. Islamists believed that the main cause of the decline was the denial of the basic teachings and values of Islam. It aimed to keep all Muslim people united politically, through giving them a sense of Islamic socio-political identity. ${ }^{25}$ The Panislamism of Abdülhamit can be seen as a counter-thesis against the pan-ideologies that emerged in the West, a means of defense in the times when imperialism gathered strength. ${ }^{26}$ In other words, the ideology of Pan-Islamism emerged as a

${ }^{24}$ Şükrü Hanioğlu, Osmanlıcılık, Tanzimat'tan Cumhuriyete Türkiye Ansiklopedisi, Vol.V, (İstanbul:İletișim Yayınları), s. 1390.

${ }^{25}$ Mümtazer Türköne, İslamcllığın Doğuşu, (Ankara: Lotus Yayınevi, 2003), p. 25.

${ }^{26}$ Şerif Mardin, “19. yy'da Düşünce Akımları ve Osmanlı Devleti”, Tanzimattan Cumhuriyete p. 348. In this subject, Niyazi Berkes thinks differently: According to him, the Pan-Islamism of Abdulhamit II was neither a policy against Pan-Slavism, nor an ideal as unifying all the 
reaction to the nationalist, rationalist and positivist ideas of Western civilization and to the expansionist nature of all kinds of imperialism. ${ }^{27}$ Anti-Westernism came to the fore during the reign of Abdülhamit II, as western culture was considered to be harmful and negative; traditional values were given greater emphasis, yet they were not averse to the use of western technology. The Islamists also accepted that the West was more developed than the Ottoman State. Therefore, they supported the adoption of the Western technology, but opposed the imitation of the West for they believed Europe was weak in terms of ethics and morality. In this context, Şemsettin Günaltay writes "Europe only thinks of itself; its aim is to exploit other countries. We should not expect help from Europe and we have to awaken ourselves". Mehmet Akif as well accepts Western technical superiority but refuses to imitate the West: "By imitating the religion, by imitating the customary practices, the clothes, by imitating the way people greet each other, in short by imitating every single thing, a real social community cannot emerge and live." They thought that the only way to prevent the policies adopted by the West on Ottoman Empire and other Muslim countries was a "Union of Islam".

\section{Occidentalism}

Occidentalism that was seen as a must in the Ottoman Empire is not peculiar to the Second Constitutional era. As mentioned above, from the period that the Empire began to lose ground against the West in economic, political and military areas, attempts to prevent the decline were made by adopting the Western techniques, educational institutions, and legal system. Although during the reign of Abdülhamid II, pro-Western movement which declined in face of anti-Western attitudes it still continued in technical field. The Port Arthur victory of the Japans in 1905 against Russia was seen differently by different groups of thought. The pro-Western people

Muslims of the planet. The Pan-Islamism of Abdulhamit, a realist, was a movement against the Arab sheiks, mehdis, the governors of Egypt, and the separatist Arab movements in Egypt, Syria, and Yemen. Niyazi Berkes, Türkiye'de Çă̆daşlaşma, pp. 364.

${ }^{27}$ Şaban Çalış, "Origins of Modern ..." also see. Mortimer, Faith and Power, p. 80 . 
linked the Japanese victory against a European power to its Westernization efforts, while the traditionalists have seen the victory related to Japanese adoption of Western technology without losing their identity. ${ }^{28}$ However, that the idea of Westernization becomes systematic and is seen as the primary problem of the nation from 1908 onwards ${ }^{29}$ the main supporters of Westernization managed to make their voices heard at Abdullah Cevdet's journal "İçtihad". Their main point was that the Western superiority had an unquestionable basis which was science, and there was no logic in confronting it. However, they can be analyzed in two groups. According to the moderate modernizers, technique may be transferred from one country to another but civilization could not. ${ }^{30}$ Those moderate modernizers as Celal Nuri (Illeri), advocated that what is good for the society's development should be taken from the West and developed within the traditional values, and accused Tanzimat reformers to blindly imitating Europe. On the other hand, for extreme Westernizers, the solution was more, not less, Westernization. At this point, they were criticizing the reformers before them for not going as far as necessary. For the latter, Westernization was not an issue of choice, but was a matter of survival. Abdullah Cevdet states on the subject "There is no alternative civilization; civilization means European civilization; and we have to accept it with its roses and its thorns". ${ }^{31}$ As in other ideological currents, westernization was another thesis developed by the Ottoman intelligentsia to save the state. The intellectuals considered the west as a power, and argued that westernization was the way to cope with it.

${ }^{28}$ Renée Worringer, "Sick Man of Europe or Japan of the Near Near East?: Constructing Ottoman Modernity in the Hamidian and Young Turk Eras," International Journal of Middle Eastern Studies, No. 36, 2004, pp. 207230.

${ }^{29}$ Şükrü Hanioğlu, "Batıcılık", Tanzimattan Cumhuriyete Türkiye Ansiklopedisi, Vol. V, (İstanbul:İletişim Yayınları, 1985), p. 1383.

${ }^{30}$ Tunaya, "Garpçılık," Tanzimattan Cumhuriyete Türkiye Ansiklopedisi, Vol. V, (İstanbul:İletişim Yayınları, 1985), p. 594.

${ }^{31}$ İçtihat, no:89 (Hicri 1329), s. 1890. Tarık Zafer Tunaya, "Garpçılık", p. 590. 


\section{Pan-Turkism}

The emergence of Turkish nationalism is far later than its western counterpart. It is due to the fact that the Turks were the core element of the empire; thus if Turks had came up with the idea of Turkish nationalism, this might have constituted an example to the others. Another and possibly more important reason is the creation of bourgeois and labor classes in other nations before the Turks. ${ }^{32}$ The start of the Turkish nationalism as a concept owes to the Turcology studies in the $19^{\text {th }}$ century Europe. ${ }^{33}$ This field of science researched Turks on their Asiatic roots, provided information on their bright past before their conversion to Islam, and emphasized the linguistic links among the various Turkic groups. It could not be expected that the works of European Turcologists would not affect Ottoman intellectuals who were in an ideological vacuum and who tried to find a solution to the decline. A channel these ideas reached the Turks living in the Empire was the student corps sent to the European universities. Another channel of communication was the Hungarian exiles who settled in the Empire after the 1848 revolutions. These developments started taking effect during the reign of Abdülhamit II, despite all the censorship and prohibitions he applied.

Another source which affected the Turkist current in the Ottoman Empire was the Turks in Russia. Among the Muslims of Russia, especially among the Tatars of Volga, the idea of nationalism arose before the Turks of the Empire. ${ }^{34}$ When the reasons for that are considered in terms of economic and cultural perspectives, it is understood that the Volga Tatars were the most advanced amongst the Muslims of Russia. Despite suffering from the Russian pressure in the centuries which followed the invasion, with the rise of Catherine II to power, the balances have changed and the Tatars were

${ }^{32}$ Sina Akşin, "Türk Ulusçuluğu," Cumhuriyet Dönemi Türkiye Ansiklopedisi, Vol.VI, (İstanbul: İletişim Yayınları, 1985), p. 1943.

${ }^{33}$ Gencay Şaylan, "Milliyetçilik, İdeoloji ve Türk Milliyetçiliğii”, Cumhuriyet Dönemi Türkiye Ansiklopedisi. The reason for these researches was to know oneself as well as knowing the foreigners. Researches on history, linguistics, philosophy were started in this subject.

${ }^{34}$ S.A.Zenkovsky, Pan-Turkism and Islam in Russia, (Cambridge: Harvard University Press, 1960). 
granted a kind of religious and civil autonomy. More importantly, they became intermediaries in the trade between the rich Central Asian markets and the West that the Russian failed to penetrate due to religious differences. This advantage gave way to the rise of a rich traders' class among the Tatar community. ${ }^{35}$ On the other hand, when we look at the Turks living in the Empire, we can see that they did not have a special place within the millet system of the Empire and that they constituted the dominant millet with the other Muslims of the Empire (Arabs, Kurds, Albanians), that there were no ethnic barriers between them, and that the Ottoman Turks have adopted Islamic culture in full. ${ }^{36}$ The main sign for this is the answer to the question of how they saw their own culture traditionally. Ottoman historiography based basically on two issues: the role assumed by Muhammad the Prophet, and the rise of the Ottoman dynasty. The link between these two issues was provided by the Seljuks. ${ }^{37}$ In other words, the pre-Islamic past of the Turks, their Asian roots were forgotten. For this reason, while ideas of nationalism penetrated among other nations of the Empire, such as the Greek independence and Serbian autonomy, no signs of Turkish-Ottoman consciousness emerged at that time. During the last quarter of the $19^{\text {th }}$ century, to oppose the strengthening Pan-Slavist movement of Alexander III and the Russification movement, reforms were undertaken by the Tatar community. ${ }^{38}$ After the seizure of Crimea by the Russians, a big Tatar migration took place toward Ottoman Empire and this migration continued in great waves after the Ottoman-Russian War in 18771878 , locating a large number of Tatars, Azerbaijanis, and Caucasian Turks to the Empire. By the end of the same century, improvements in railroad making, an increase in naval transport, made the Turks in Russia become closer to both themselves and the Ottoman Empire. With the development of the means of communication and with the influence of Turkish intellectuals who had to give a fight of identity against the repressive Russian regime and who fled to Ottoman Empire, Panturkism began to find supporters among the Turks of the Ottoman Empire, too.

\footnotetext{
${ }^{35}$ François Georgeon, Türk Milliyetçiliğinin Kökenleri: Yusuf Akçura, (Çev. Alev Er), (Ankara:Yurt Yayınları, 1986).

${ }^{36} \mathrm{Ibid}$, p. 47.

${ }^{37}$ Bernard Lewis, Emergence of Modern Turkey, pp. 329-330.

${ }^{38}$ Georgeon, Türk Milliyetçiliğinin Kökenleri, p. 17.
} 
The major advocate of the Panturkist ideology among the Turks in Russia was İsmail Gaspıralı (1851-1914), a Crimean Tatar. Gaspiralı, stated his idea of unity among Russian Muslims and Turks with the motto of his Crimean newspaper Tercüman, "unity in language, ideas, deeds". ${ }^{39}$ Gaspiralı who defended the concepts of Turkism and Islam, was also in favor of Westernisation. The "usuliCedid/New Method" program he initiated was serving this aim. Yet, he foresaw the line of modernization looking to West was necessary for the continuity of the concepts of Turkism and Islam. They were to decay in underdevelopment lest they faced up the requirements of modernization. In other words, following the Western path was a matter of life or death in order not to be left behind the developed nations of the West. ${ }^{40}$

The idea of a unique Turkish-Muslim identity that would cover all the Russian Muslim Turks and based on ethnic and religious bases that Gaspiralı wanted to impose through the newspaper had began to be supported by the intellectuals. Gaspiralı had avoided formulating a political Turkish identity and had prepared the social and cultural background of this union, leaving the political union to others. One of those "others" who founded the political Pan-Turkism was a Tartar of Kazan, Yusuf Akçura / Akçuraoğlu41 (1876-1935). He was comparing the three political approaches pursued by the Union and Progress Party and was calling for a unification of Turks who were facing the Western imperialism in his 1904 article " $\ddot{U}_{\zeta}$ Tarz-I Siyaset" (Three Ways of Policy) which was considered as the

${ }^{39}$ Nadir Devlet, İsmail Bey (Gaspıralı), (Ankara: Kültür ve Turizm Bakanlığı, 1988). Hakan Kırımlı, "İsmail Bey Gaspıralı, Türklük ve İslam”, Doğu-Batı, No. 31, (April 2005), pp. 147-176.

${ }^{40}$ Kırıml, "Issmail Bey Gaspıralı, p. 169.

${ }^{41}$ Although Akçura and Gasprinski share many ideas, the major difference between the two emerged from the priorities they gave to Islam and Turkism. For Gaprinski, Islam ranked first, and for Akçura, Turkish nationalism was a far more important ideal. Ü̧̧ Tarz-ı Siyaset, s. 50.For further information see, David Thomas, "Yusuf Akçura and the Intellectual Origins of Üç Tarz-1 Siyaset”, Journal of Turkish Studies, 2:1978, pp. 127140. 
manifesto of Panturkism, published in the journal "Turk". 42 Ottomanism, Islamism and Turkism were seen in different intervals as the ideology of Union and Progress in the period 1908-1918. As stated above, the idea of Ottomanism was put forward by intellectuals and the government since the Tanzimat. The Union and Progress valued this idea since it was established as a secret society in Thessaloniki. It was seen as the most intelligent idea to save and develop a multinational state. Until the Balkan Wars, the policy of "İttihad-1 Anasır" (the unity of constituents) remained the dominant policy in terms of its main framework. The 1912-1913 Balkan Wars was the turning point of the "Ittihad-1 Anasır" policy. From the war onwards, the Turkist movement which became popular after 1908 Revolution ${ }^{43}$ changed the way the Turks were seen as "Etrak-1 bi İdrak" (unintelligent Turks). The continuous attempts of Great Powers to intervene in the affairs of the Ottoman Empire under the disguise of protecting the minorities caused the young intellectuals to adopt Turkish nationalism vigorously. A coherent effort combining different aspects of the Ottoman State and Western style modernization came from Durkheim's follower Ziya Gökalp. ${ }^{44} \mathrm{He}$ has attempted to develop these ideas a short while after the Young Turk Revolution in the articles he wrote for the journal Türk Yurdu, ${ }^{45}$ published by the Türk Derneği Örgütü46 (Turkish Association Organization) led by Yusuf Akçura. ${ }^{47}$ Turkish nationalism formulated by Ziya Gökalp, has become the dominant ideology especially after the Balkan Wars, and has gained an economic dimension within this framework. The economic dimension of Turkish nationalism emerges with the Union and Progress's "National Economy Program". This program may be described as aiming at discharging the minority or

${ }^{42}$ Masami Arai, Jön Türk Dönemi Türk Milliyetçiliği, Çev. Tansel Demirel, (İstanbul: İletişim Yayınları, 1994).

${ }^{43}$ Tevfik Çavdar, İttihat ve Terakki, (İstanbul: İletişim Yayınları, 1994).

${ }^{44}$ Jacob M. Landau, "Kültürel ve Siyasi Pantürkizm", Osmanl Ansiklopedisi, Vol. VII, p. 493.

${ }^{45}$ For the associations established to develop the idea of Pan-Turkism and their publications, see Masami Arai, "Between State and Nation: A New Light on the Journal Turk", Turcica (Paris), 24: 1992, pp. 277-295.

${ }^{46}$ The date of the association's establishment is 6 January 1909. Fethi

Tevetoğlu, Müftüoğlu Ahmet Hikmet, (Ankara:1986), p. 80.

${ }^{47}$ Yusuf Akçuraoğlu, Türk Yılı: 1928, (İstanbul, 1928), p. 435. 
foreign tradesmen, bankers, entrepreneurs, and replacing them with Turks, that is creating a Turkish bourgeoisie.

In his article "New Ottomans / Yeni Osmanlılar", Ziya Gökalp states that Ottoman civilization would emerge from Eastern spirituality and Western materialism. For him, the Ottomans should neither be imprisoned in the Eastern civilization nor should they be blind imitators of the West. ${ }^{48}$ In his article titled "Üç Akım / Three Currents" he argues that it was time to head for the Western civilization from Islamic civilization, and describes the Turkish nation as a member of the Altaic language family, Islamic congregation, European union of states (civilization). Gökalp sees no harm in adopting Western science and technology. ${ }^{49}$

By 1914 the most dominant ideology in the Empire was Panturkism. The advocates of this ideology started to affect the public opinion and foreign policy with their articles. As can be seen in the articles of Yusuf Akçura, alliance with Germany was supported. AntiRussian strategies were discussed and Russia was presented as the greatest obstacle on the way to achieve the Turkish unity. Where would Ottoman Empire take its place within the new system of alliances of Europe? When France, the traditional ally of the Empire allied with Russia, the Panturkist perspective eliminated this country at once. As for Britain, although this country has defended the Ottoman territorial integrity throughout the $19^{\text {th }}$ century, the Ottomans knew it was for securing the British route to India. Thus, these observations of Panturkists, a group that included both some of the power holders and intellectuals, led them to seek alliance with Germany. One can see these considerations in the secret treaty concluded with Germany one day before the Russian declaration of war on Germany and her allies. ${ }^{50}$

${ }^{48}$ Ziya Gökalp, Makaleler-I, (Ed.) Şevket Beysanoğlu, (Ankara, 1976), p. 64.

${ }^{49}$ Ziya Gökalp, Makaleler -II, (Ed.) Süleyman Hayri Bolay, (Ankara, 1982), p. 25.

${ }^{50}$ The cited agreement was concluded by the premier Halit Pasha, Enver Pasha, Talat Pasha, and the speaker of the parliament Halil Bey on 2 August 1914 at Sait Halim Pasha's private residence on the Bosphorus. The most important article of the eight-article agreement foresaw that if Russia entered the conflict and Germany was also to be taking part, then 
The rise of Turkism, a political movement based on the idea of a Turkish nation and not on a dynasty, or religion took place in a period where Ottomans were defeated and Muslims were humiliated, feeding on various developments: the Ottoman reaction against separatism in the Balkans, the Tatar rebellions against Russian Panslavism, the new ideas brought forward by European nationalism and the works on Turcology, in a period where Ottomans were defeated and Muslims were humiliated. ${ }^{51}$ Even if the ideology of Ottomanism ideology after the Balkan Wars and Panturkism ideology after World War I could not become more than fantasies, ${ }^{52}$ these ideological discussion which began in the $19^{\text {th }}$ century carried on in a different perspective after the World War I. The idea of "selfdetermination", i.e., the principle that nations should choose their own destiny, and the policies that Union and Progress pursued during the war which foresaw ethnic reconstruction that covered not only non-Muslims but all nations of the empire, ${ }^{53}$ had alighted old discussions once again, but with a difference: the question now became "how to institutionalize the state that would replace the fallen empire", instead of the one "how to save the empire". Turkish nationalism observed in this period developed in essence as a search for a Turkish unity and as a reaction to the objectives of the Greek and Armenian minorities who wanted to rid themselves of the Ottoman rule. On the other hand, it can be seen that Ottomanism was brought into the agenda once more. There were ideas that criticized the Union and Progress's Turkification policy, that stated that this policy weakened the link of Ottomanism and caused the Armenian and Greek minorities to put a distance between them and the state. They were thinking that the idea of Ottomanism should be reconstructed: many unhappy event had taken place due to the wrong policies of the Union and Progress, but as these policies were now defunct, then the past might be forgotten and the future might be

Ottoman Empire would join the Axis powers. Eric Jan Zürcher, pp. 165166.

${ }^{51}$ Lewis, Emergence of Modern Turkey, p. 346.

${ }^{52}$ Jacob M. Landau, "The Fortunes and Misfortunes of Pan-Turkism", Central Asian Survey, 7 (1): 1988, pp. 1-5.

${ }^{53}$ Fuat Dündar, Ittihat ve Terakki'nin Müslümanlarl İskan Politikası (19131918), (İstanbul: İletişim Yayınları, 2001). 
reconstructed. ${ }^{54}$ As a result of some developments such as, the boycott of the 1919 elections by the Greek and Armenian minorities, the ethnic based division of Anatolia in the 1920 Sevres Treaty, the idea that the nations that were treacherous to the Empire should be dealt with began to gain ground. The basis that the Turkish nationstate would rest on the Lausanne Treaty were to be Turkish nationalism. ${ }^{55}$

\section{Conclusion}

How could the Ottoman Empire have been saved? That was the question all ideologies sought an answer for. Although each supplied different answers, one cannot say there were irreconcilable differences between them. There was no such thing as one cannot defend one of these ideological currents and couldn't defend another. Many Young Turks who defended Ottomanism, were at the same time practicing Muslims as well as romantic Panturkists who were deeply entrenched in nationalism ${ }^{56} \mathrm{~A}$ majority of the intellectuals were in favor of accepting those parts of the Western civilization they considered positive. Those who supported Ottomanism accepted that, so did Westernization supporters and so did even the Panislamists. The Young Ottomans who aimed at unifying all the elements in the Empire under the Ottoman rule were on the one hand criticizing the Tanzimat reforms as a blind imitation of the West, and on the other hand, they were taking their point of origin from the values of the West. Panislamism which adopted Islamic practices and cooperation among the Muslim communities was defending a return to traditional values but was also in favor of using Western techniques. The Union and Progress were using a Western thesis to confront the West: nationalism. They, especially after 1913, favored Panturkism and put this ideology to the forefront against Russia during World War I, were at ease in using Panislamist ideas at such times as the times they

\footnotetext{
${ }^{54}$ Nesim Şeker, "Türklük ve Osmanlı Arasında: Birinci Dünya Savaşı Sonrası Türkiye'de "Milliyet" Arayışları ya da "Anasır Meselesi", Erik Jan Zürcher (der.), Imparatorluktan Cumhuriyete Türkiye'de Etnik Çatışma, (İstanbul:İletişim Yayınları, 2005), pp. 157-175.

${ }^{55}$ Şeker, Ibid., p 168.

56Zürcher, Modernleşen Türkiye'nin Tarihi, p. 187.
} 
needed Arab loyalty or as in their declaration of Jihad in 1914, when their political interests required it. ${ }^{57}$ Ziya Gökalp, a prominent advocate of Turkism, argued that Western manners should be accepted, was also criticizing the Tanzimat reformers for their loss of contact with their own nation's culture. The idea of Ottomanism tried to be revived during World War I became impossible with the Sevres Treaty and the idea of unification of all Turks became null and void in the wake of the Russian Revolution and the Turkish War of Independence. After this ideological confusions seen in the $19^{\text {th }}$ and early $20^{\text {th }}$ centuries, modern Turkey which rose off the ashes of Ottoman Empire ${ }^{58}$ was located on a far sounder and decisive ideology.

Mustafa Kemal opposed to the ideologies of Pan-Ottomanism, Pan-Islamism and Pan-Turkism. He was saying that Turks had deeds to do in Turkey, and adoption of any other policy would be nothing but adventure. ${ }^{59}$ The new nationalism in the Republic of Turkey aimed at saving and developing the Anatolian Turks. Therefore, this nationalism was very different from nationalism of the Young Turk era. However, it won't be wrong to say that the Young Turk nationalism was a means to awaken the Ottoman Turkish to the existence of a national conscience which was perceived far too late. Atatürk had two major aims: the establishment of a sovereign and independent Turkish state and to accomplish this state's modernization. ${ }^{60}$ For these reasons, even during the War of Independence the link with the Sultan was broken; the sultanate was abolished on 1 November 1922 and the Caliphate on 3 March 1924. By these reforms, Atatürk wanted to a strong break from the past. His reforms constituted a coherent and systematic inclination towards the West and aimed at reaching the cultural, industrial, and economic

${ }^{57}$ G.L.Lewis, "The Ottoman Proclamation of Jihad in 1914", Islamic Quarterly: A Review of Islamic Culture, 19 (1-2), 1975, pp. 157-163.

${ }^{58}$ This figure of speech belongs to Oral Sander in his Anka'nın Yükselişi ve Düşüşü, (Ankara: 1993).

${ }^{59}$ Söylev I, p. 193.

${ }^{60}$ For detailed information in Atatürk's thoughts on inclination toward the West, see Mehmet Gönlübol, Atatürk's Foreign Policy: Goals and Principles, in Feyzioglu, Turhan (ed.), Atatürk's Way, (İstanbul: 1982), p. 255-302. 
level of the European states. Atatürk's success derived from his belief to accept European civilization as a whole, whereas earlier reformers had only tried to imitate Europe with limited success. ${ }^{61}$ Atatürk expressed his desire for westernization "to reach the level of contemporary civilizations." 62 Western civilization was chosen "not for it is the civilization of the West, but because it represents the modern civilization which incorporates values created by entire humanity in thousands of years by adding an independent, scientific, and rationalist philosophy of life." 63

${ }^{61}$ See, Baskın Oran, Az Gelişmiş Ülke Milliyetçiliği , (Ankara: Bilgi Yayınevi, 1997), pp. 28.

62İlhan Selçuk, “Avrupa'ya Anadolu'dan Girilir”, Cumhuriyet, 14 November 1997. Bozkurt Güvenç emphasizes the following point: "Kemalist Revolution was committed to building a contemporary society and modern nation along the Western lines. The emphasis, however, was on modernity and development; not imitation but creation. Western sources and resources were examined, adapted but not adopted.(...) The goal was not Westernisation but modernisation, that is, development and progress in time-space. " Bozkurt Güvenç, "Quest for Cultural Identity in Turkey National Unity of Historical Diversities and Continuities," Zeitschrift für Türkeistudien, (1994) 7, s. 186-187.

${ }^{63}$ Afet İnan, Mustafa Kemal Atatürk'ten Yazdlklartm, (Ankara: 1971), p. 37. 